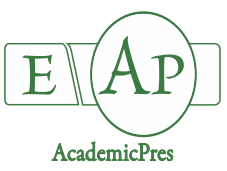

Notulae Botanicae Horti Agrobotanici Cluj-Napo
DOI:10.15835/48412097
Research Article

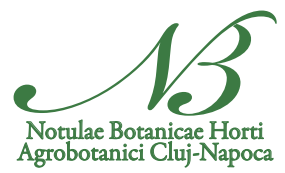

\title{
Pomological and phenological characteristics of the main pistachio cultivars in Greece
}

\section{Ioannis MANTHOS ${ }^{1 *}$, Dimos ROUSKAS ${ }^{1}$, Evangelos KARAGIANNIS ${ }^{2}$, Thomas SOTIROPOULOS ${ }^{3}$, Athanasios MOLASIOTIS ${ }^{2}$, Mihai BOTU ${ }^{4,5 *}$}

\author{
${ }^{1}$ Hellenic Agricultural Organization-DEMETER, Institute of Plant Breeding \& Genetic Resources, Department of Nut Trees, Neo \\ Krikelo,Lamia 35100,Greece; manthosjo@yahoo.gr (corresponding author);dimosrouskas@hotmail.com \\ ${ }^{2}$ Aristotle University of Thessaloniki, Faculty of Agriculture, University Campus, 54124 Thessaloniki, \\ Greece; karagiee@agro.auth.gr; amolasio@agro.auth.gr \\ ${ }^{3}$ Hellenic Agricultural Organization-DEMETER, Institute of Plant Breeding \& Genetic Resources, Department of Deciduous Fruit \\ Trees, 38 SS Naoussa, 59035 Naoussa, Greece; thosotir@otenet.gr \\ ${ }^{4}$ University of Craiova, Faculty of Horticulture, Department of Horticulture and Food Science, Str. 13 Al. I. Cuza, Craiova, \\ Romania;btmihai2@yahoo.gr (correspondingauthor) \\ ${ }^{5}$ University of Craiova, SCDP Vâlcea, 464 Calea lui Traian, Rm. Vâlcea 240273, Romania;
}

\begin{abstract}
The present study aimed to evaluate the pomological and phenological traits, as well as kernel antioxidant potential of the dominant Greek pistachio cultivars, 'Aegina' and 'Pontikis' (Pistacia vera L.). Blooming of 'Aegina' cultivar occurred from early to mid of April, and nut maturation at middle to late of August. Production started at 6 to 7 years from grafting and full production observed at year 13. Blooming and nut maturation of 'Pontikis' occurred about 1 to 2 days later than 'Aegina' and production started 6 to 7 years from grafting, with full production observed in the 14th year. Mean tree yields reached $18.0 \pm 1.0 \mathrm{~kg}$ and 17.4 $\pm 1.1 \mathrm{~kg}$ of dry nuts, in 'Aegina' and 'Pontikis' cultivar, respectively. 'Aegina' cultivar presented intermediate tree vigour and spreading growth habit, whereas 'Pontikis' high tree vigour and semi-erect growth habit. 'Aegina' nut had a narrowly cordate shape and the percentage of split nut was found at $78.5 \pm 6$.5. 'Pontikis' nut had ovoid shape and the percentage of split nut was $84.1 \pm 6$.2. In 'Aegina' cultivar 100 nuts weighted 101.0 $\mathrm{g}$ and in 'Pontikis' $114.4 \mathrm{~g}$. Color of kernel was green externally and green to green-white internally, greener in 'Pontikis'. The antioxidant potential of pistachio kernel measured by FRAP assay, total polyphenolic substances, flavonoids, flavanols and hydroxycinnamic acids content, did not differ $(\mathrm{P}>0.05)$ between cultivars. Evaluation of 'Aegina' and 'Pontikis' pistachio cultivars revealed that both are high yielding, with large nut sizes of acceptable appearance and high quality.
\end{abstract}

Keywords: Greek pistachio cultivars; nut characteristics; Pistacia vera; nut antioxidants

Abbreviations: 2,2-diphenyl-1-picrylhydrazyl (DPPH); ferric reducing antioxidant power (FRAP); fruit weight $(\mathrm{fw})$; principal component analysis (PCA); Protected Designation of Origin (PDO); total antioxidant capacity (TAC); total flavonoids (TF); total phenolics (TP) 


\section{Introduction}

Pistachio (Pistachia vera L.) is one of the most important tree nuts for human consumption and its cultivation is found in dry and hot areas, under saline conditions (Metheney et al., 1998). It is cultivated in the Middle East, United States, and Mediterranean countries. Greece is among the most important pistachio producing countries worldwide (in 6th position) and the first producing EU country, with 4,500 ha cultivated area and 12,300 tons annual production (FAO Stat, 2019). Pistachio fruits are an excellent source of two B complex vitamins, niacin and folic acid. They also contain phytosterols, substances that in high amounts help to reduce the absorption of cholesterol. They also improve total and high-density lipoprotein cholesterol levels, and exert very important antioxidant properties (Kocyigit et al., 2006).

There are four Pistacia species native to Greece, namely Pistacia paleastina, P. terebinthus, P. atlantica and $P$. lentiscus, whereas only $P$. vera was introduced from Eastern Mediterranean countries by the Romans and subsequently by Byzantines (Zohary, 1952). The cultivated species, $P$. vera, was introduced in 1869 in an area close to Athens. By 1950s P. vera had spread in other dry and warm areas of Greece, including Aegina island were pistachio cultivar was established and expanded (Katsiotis et al., 2003). At the onset of its cultivation, $P$. terebinthus was used as rootstock, but later was replaced by the 'Tsikoudia' a variant of $P$. paleastina, because of its good compatibility with $P$. vera and its tolerance to Phytophthora attacks (Padulosi and Hadj-Hassan, 2001).

Pistachio is of particular importance for Greece, as it is cultivated mainly in lowland and semimountainous areas of the country, in arid regions and can exploit a variety of soils, from slightly acidic to alkaline, even without irrigation. However, one or two irrigations give much better results (Rouskas, 2005). Pistachio orchards can be found in different places in Greece, from South to North. There are also pistachio orchards in many islands of the Aegean Sea. More than 1.2 million trees are recorded in plantations (Rouskas and Zakinthinos, 1994). The great expansion in pistachio cultivation took place some years ago. The most widespread cultivars grown in Greece are 'Aegina' and 'Pontikis', while other cultivars are 'Nichati' and 'Fountoukati', with unknown origin (Rouskas and Zakinthinos, 1994). It is believed that they were all seedling selections from the introduced trees, but no records exist about their pedigrees.

'Aegina' cultivar has taken its name from Aegina Greek island, where it is the most cultivated (Katsiotis et al., 2003). The famous 'Aegina' pistachio from the Aegina island has been designated as a Protected Designation of Origin (PDO) product by the EU (EC 1263/96) because of its desirable green kernel and high fat content, which gives the nut a particularly spicy taste when roasted and salted. This cultivar originated from seedling selection (most likely of the 'Ashoury' cultivar), whereas 'Pontikis' cultivar originated from a seedling selection obtained by professor C.A. Pontikis from the 'Aegina' cultivar. Initially, 'Aegina' cultivation was restricted to the coasts of Attica and Aegina. From 1950 it began to expand in the areas of Viotias, Corinthos, Evias and of Fthiotidas and from 1968 its cultivation expanded in central and northern Greece (Thessaloniki, Halkidiki, Rodopi), in Crete and Cyclades. 'Pontikis' cultivar is cultivated mainly in Thessaly, but recently its cultivation has been expanded in other areas, as 'Aegina' (Georgiadou, 2009).

Three different selections are used as pollinators for 'Aegina' and 'Pontikis' cultivars. 'Selection A', 'Selection B' and 'Selection C'. Blooming of 'selection A' takes place 7-15 days before 'Aegina'. Its traits such as leaves, vegetative buds and trunk colour are similar to those of 'Tsikoudia'. 'Selection B' includes very vigorous trees, characterized by early blooming, whereas 'Selection C' is characterized by intermediate vigour similar to those of 'Aegina' and late blooming (Padulosi and Hadj-Hassan, 2001).

Most pistachio varieties for sufficient dormancy interruption, require approximately 1000 chilling hours (temperatures below $7{ }^{\circ} \mathrm{C}$ ) during the winter season (Chandler et al., 1937). Data of Dept. of Nut Trees of Institute of Plant Breeding \& Genetic Resources (unpublished) show that low temperatures $\left(<7^{\circ} \mathrm{C}\right)$ during the winter, on the northern regions of Greece, are sufficient to interrupt the dormancy of the pistachio varieties, resulting in smooth flowering time and selection of suitable pollinators. However, for many regions of Southern Greece with warmer winters, particular attention must be paid to the selection of pollinators, because some 
years they do not sufficiently meet the chilling requirements of the most demanding cultivars, resulting in confuses in flowering. Thus, the 'Selection A' and 'Selection B' that have lower requirements of low temperatures, bloom long before 'Aegina', while the more demanding male 'Selection C' blooms after 'Aegina' flowering and pollination may become problematic to impossible (Rouskas et al., 2006).

To our knowledge, there not any data available concerning the two cultivars characteristics cultivated in the conditions of central Greece. In this regard, the present study aimed to evaluate the pomological and phenological traits, as well as nut characteristics and kernel antioxidant potential of the dominant pistachio cultivars in Greece, 'Aegina' and 'Pontikis', that are established in the collection of Institute of Plant Breeding \& Genetic Resources, Dept. of Nut Trees, situated in the central part of Greece.

\section{Materials and Methods}

\section{Studyarea}

The study was carried out at the Institute of Plant Breeding \& Genetic Resources, Dept. of Nut Trees, Hellenic Agricultural Organization-DEMETER, Lamia, Fthiotida, Greece (GRC) (Figure 1), at 38 49'36" N $22^{\circ} 26^{\prime} 27^{\prime \prime} \mathrm{E}$ coordinates and at an elevation of $15 \mathrm{~m}$ and a slope of about $1 \%$. The two cultivars evaluated ('Aegina' and 'Pontikis') were grafted on seedling rootstocks from Pistacia terebinthus L., cv. 'Tsikoudia' and were planted in 1990, at distances of $7 \times 7 \mathrm{~m}$. The main pollinators used were 'Macho 502' and the Greek 'Selection C'. Irrigation was performed by pipes with four micro drippers of $30 \mathrm{l} / \mathrm{h}$ around each tree. Generally, the same standard cultivation (fertilization, irrigation, pruning, pest and disease control) care was applied to all trees.
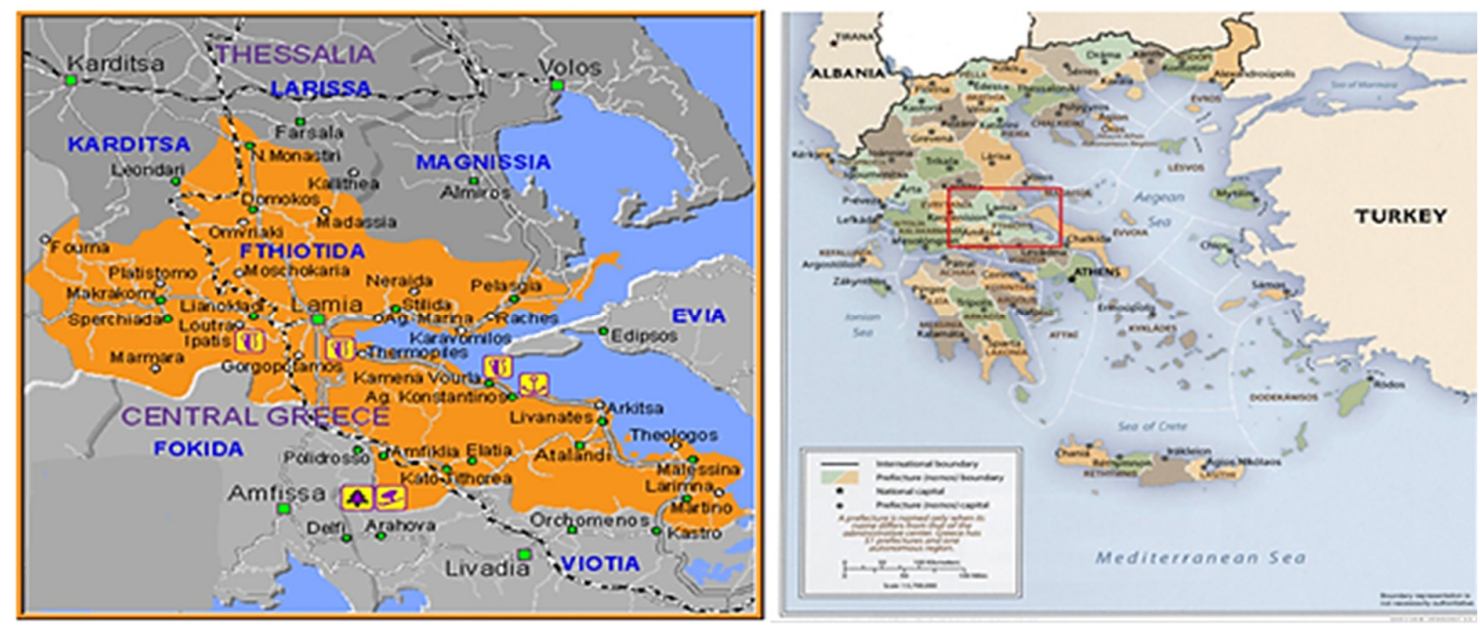

Figure 1. Geographical position of the investigated area

Source: http://www.maps-of-europe.net/maps-of-greece/;

http://www.travelgreece.org/greece.php?/loc1=central_greece\&loc2=fthiotida\&pagetype=map

Soil examination (at 0-30 cm, 30-60 cm, and 60-90 cm depth), before installing the collections, provided the following: mechanical soil composition (Bouyoukos hydrometer method; Bouyoukos, 1951): clay 52-56\%, silt $32-36 \%$, sand $8-14 \%$, soil characterization clayey. Water saturation $65-70 \%$, electrical conductivity 0.55 $0.59 \mathrm{mS} / \mathrm{cm}$, total salts $0.2 \%$, pH 7.7 (Jackson, 1958).

\section{Evaluation environment and tree condition}

Collection of all data were taken on mature, vigorous trees, healthy, cropping well, by the pistachio cultivars collection kept in the Institute, in the field. 


\section{Phenological and pomological records and nut characteristics}

Pistachio phenological data of the two cultivars were obtained from eight (8) trees per cultivar, for three consecutive years (2017-2019). These data concerning period of blooming (from first bloom date, when $5 \%$ of flowers are opened, to last bloom date, when last flowers are opened) of female and male trees and the date of harvest (when hull separates easily from the shell) according to International Plant Genetic Resources Institute (IPGRI) (1997) descriptors for pistachio. Also, at the same years, the period of nut maturation was recorded (from the beginning of fruit maturation when $10 \%$ of nuts have mature pericarp to almost full maturation, when $80 \%$ of nuts have mature pericarp) according to Manthos et al. (2019).

At the same years, pomological data were recorded and concerned tree vigour, growth habit, number of leaflets, as well as nut characteristics, according to IPGRI (1997) descriptors for pistachio.

To evaluate nut characteristics, a sample of 100 pistachio nuts per cultivar each year was randomly selected at harvested time (ripe state when the hull separated easily from the shell). After fruit de-hulled, nuts were dried at $60^{\circ} \mathrm{C}$ for $24 \mathrm{~h}$, in a ventilated oven. The dried nuts were subjected to various measurements. To determine the average size of the pistachio nuts, the three linear dimensions of each of the fruits of pistachio nut namely, length $(\mathrm{L})$, width $(\mathrm{W})$ and thickness $(\mathrm{T})$ were measured with a micrometer to an accuracy of 0.01 $\mathrm{mm}$, according to IPGRI (1997) guides. Nut size index $(\mathrm{mm})$ was calculated from the equation: $\frac{(W+T+L)}{3}$ and nut shape index was calculated from the equation: $\frac{W+T}{2 * L}$ according to Mohsenin (1980). To obtain the weight (mass), each pistachio nut and its kernel was weighted using an electronic scale of $0.001 \mathrm{~g}$ sensitivity. Moreover, nut and shell apex shape, depression of shell near pedicel scar, pedicel scar shape and elevation, suture elevation and position of suture opening, percentage of split nuts, suture opening, weight of 100 nuts and 100 kernels, number of nuts in $100 \mathrm{~g}$ weight, kernel and kernels' testa color and kernel efficiency (kernel dry weight/nut dry weight $\times 100)$ were evaluated, according to IPGR (1997) guides of descriptors.

\section{Harvest condition}

Harvesting was performed mechanically at the end of August and production of each examined tree was measured every year. Tree yield per cultivar was estimated only the "on" year of full production.

\section{Meteorological data records}

Meteorological data concerning temperature during the blooming period were collected from the meteorological station that is established within the facilities of the Institute. From hourly temperatures records the mean daily temperature was calculated, as shown in Figure 2.

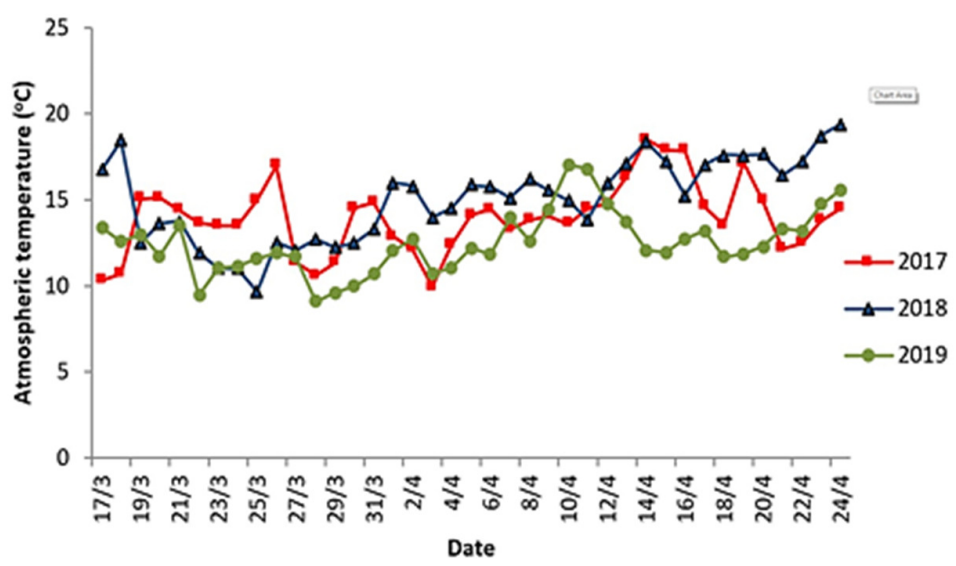

Figure 2. Mean daily temperature, during pistachio cultivars blooming, at years 2017-2019 


\section{Fruit antioxidant activity and phenolic antioxidants analysis}

Antioxidant activity of pistachio fruit of the two cultivars was determined in 20 fruit/year/cultivar using ferric reducing antioxidant power (FRAP) assay (Benzie and Strain, 1996) and antioxidant potential of the extracts was determined from a standard curve using trolox as equivalent and expressed as $\mu \mathrm{g}$ Trolox $100 \mathrm{~g}^{-1}$ fruit weight (fw). The extraction of polyphenolic substances was performed according to (Asami et al., 2003). Total polyphenols were determined using Folin-Ciocalteu methodology (Asami et al., 2003). Optical density was measured at $760 \mathrm{~nm}$ in a microplate reader (Tecan infinite M200 PRO) and the results were expressed in equivalents of mg gallic acid $100 \mathrm{~g}^{-1} \mathrm{fw}$. Flavonoids was measured at $510 \mathrm{~nm}$ according to (Karagiannis et al., 2016) and the results were expressed as equivalents of mg rutin $100 \mathrm{~g}^{-1} \mathrm{fw}$. Flavanols and hydroxycinnamic acids were determined as reported by (Michailidis et al., 2017; Obied et al., 2005). The results were expressed in equivalents of mg quercetin and caffeic acid $100 \mathrm{~g}^{-1} \mathrm{fw}$, respectively.

\section{Statistical analyses}

Data for nut characteristics (length, width, thickness, size index, shape index, nut and kernel weight, kernel efficiency and percentage of open pistachios) were statistically analyzed with descriptive statistics. Data are presented as mean \pm SD. Data concerning the antioxidant potential of pistachio fruits (FRAP, total polyphenolic substances, flavonoids, flavanols and hydroxycinnamic acids content) were analyzed using analysis of variance (ANOVA). Data are presented as mean \pm SE. For all tests, a probability level of $\mathrm{P}<0.05$ was accepted as being statistically significant. For statistical analysis the SPSS Statistics for Windows ver. 17.0 (2008) was used.

Phenotyping data were analyzed with ClustVis (Metsalu and Vilo, 2015) to determine any clusters of genotypes. To create heat maps, both rows and columns are clustered using Euclidean distance and Ward's linkage method.

\section{Results and Discussion}

\section{Phenological and pomological records}

The blooming period of 'Aegina' cultivar occurred from 4th to 17th of April during 2017-2019 period. The earliest start of blooming was observed on 4th of April 2018, whereas the latest start of blooming observed on 7th of April 2019 (Figure 3). Blooming period of 'Pontikis' cultivar was recorded from 5th to 18th of April during 2017-2019 period. The earliest start of blooming was observed on 5th of April 2018, whereas the latest start of blooming was observed on 7th of April 2019. The earliest date of start of blooming in both cultivars observed at year 2018, when higher temperatures around blooming were observed, in relation to other years of observation, as shown in Figure 1. Accordingly, the latest start of blooming observed at year 2019 was accompanied with lower temperatures around blooming this year. The blooming period of the two cultivars was occurred at the same date, in the specific environmental conditions of Fthiotida region.

Rouskas (2002) observed phenotypic characteristics of twelve cultivars, among which 'Aegina' and 'Pontikis' cultivars, from the same collection kept in the Institute, from 1990 to 2000. According to the results, the mean blooming period of 'Aegina' cultivar occurred from 9 to 24 of April. The same was the case for 'Pontikis' cultivar. 'Aegina' and 'Pontikis' had the earliest blooming date, followed by 'Mateur' and 'Red Aleppo' ( 1 day later), 'Bronte' ( 2 days later), 'Bianca', 'Cerasola' and 'Sfax' (3 days later), 'Ajamy' (4 days later), 'Kerman' ( 6 days later), and 'Muntaz' and 'Cappuccia' (7 days later). Moreover, Vargas et al. (1995) evaluated 29 females and 24 males' cultivars from 10 countries, among which 'Aegina' cultivar, for at least 3 flowering seasons. The cultivars were placed in IRTA-Mas Bové collection near the Mediterranean Sea. 'Aegina' cultivar was among the earliest female cultivars evaluated, with the mean blooming period from 30 of March to 13 of April. According to Pontikis (1986), the first evaluation of 'Pontikis' cultivar, in the collection kept in the area of Attiki, showed that this cultivar starts blooming around 15 to 20 of April. 
Blooming of pollinator 'Selection C' occurred from 2 to 20 of April and that of 'Macho 502' from 3 to 22 of April (Figure 4), depending on the year. As was the case with female cultivars, the earliest date of start of blooming observed at the year 2018, in both pollinators, when higher temperatures around blooming occurred, in relation to other years of observation and the latest start of blooming observed at year 2019, when lower temperatures occurred around blooming this year, as shown in Figure 4.

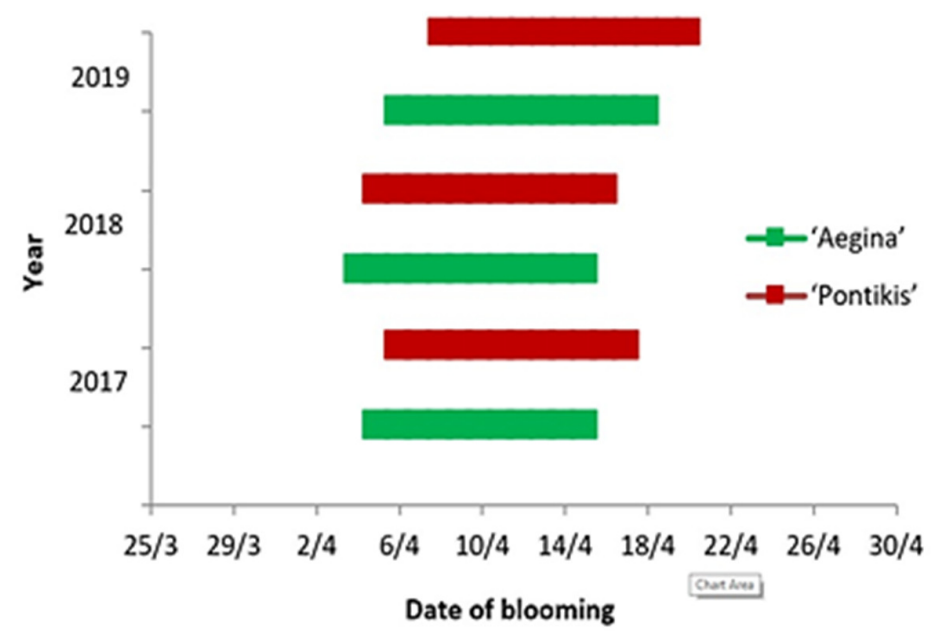

Figure 3. Blooming period of 'Aegina' and 'Pontikis' cultivar

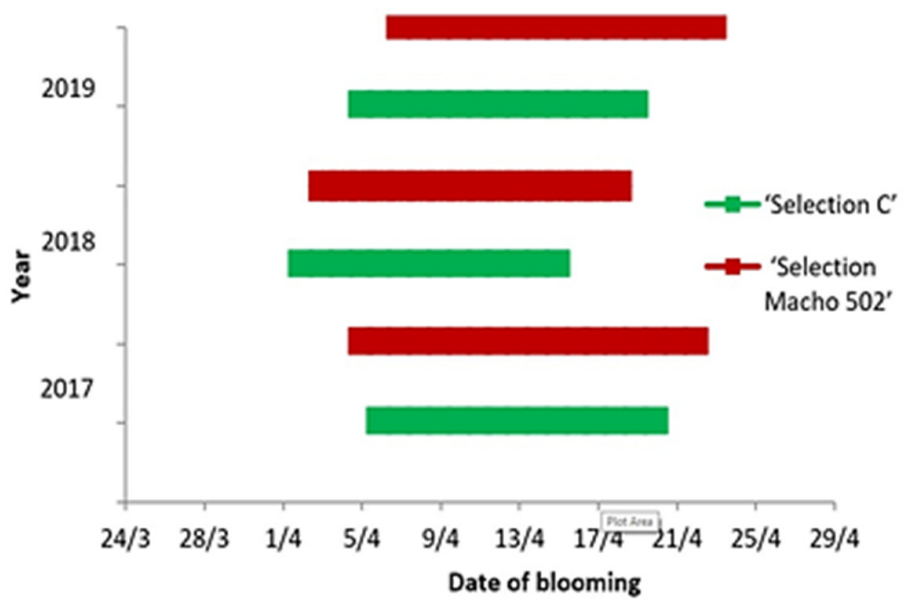

Figure 4. Blooming period of 'Selection C' and 'Macho 502' pollinators

Since, pistachio is a dioecious species, i.e. male and female blossoms are on separate trees, the male trees only needed to produce pollen for fertilizing female trees, and must be scattered around orchards at a male percentage of $12 \%$, relative to females. The male pollinator varieties are very important for the yield of female cultivars (both quantitative and qualitative). A very good pollinator should cover the entire receptive period of the flowers of the female cultivar with the emission of pollen. According to our observations, both evaluated pollinators 'Selection C' and 'Macho 502' are suitable for 'Aegina' and 'Pontikis' cultivars pollination in the area studied, since their flowering period covers the entire blooming period of the two female cultivars. According to Rouskas et al. (2006), in Greece two more pollinators are used, 'Selection A' and 'Selection B'. However, these pollinators are more suitable in the southern areas of Greece, because they required lower 
dormancy temperatures and they are flowering earlier than 'Aegina' cultivar. In the climatic conditions of the study of Vargas et al. (1995) blooming period of 'Selection C' was observed from 1 to 15 of April and that of 'Macho 502' from 2 to 17 of April.

In 'Aegina' cultivar, the period of nut maturation (10\% to $80 \%$ of fruits with mature pericarp) occurred from 13 to 25 of August and harvest occurred from 20 to 27 of August, depending on the year examined, whereas in 'Pontikis' cultivar, the period of nut maturation occurred from 13 to 26 of August and harvest occurred from 21 to 28 of August (Figure 5), depending on the year examined.

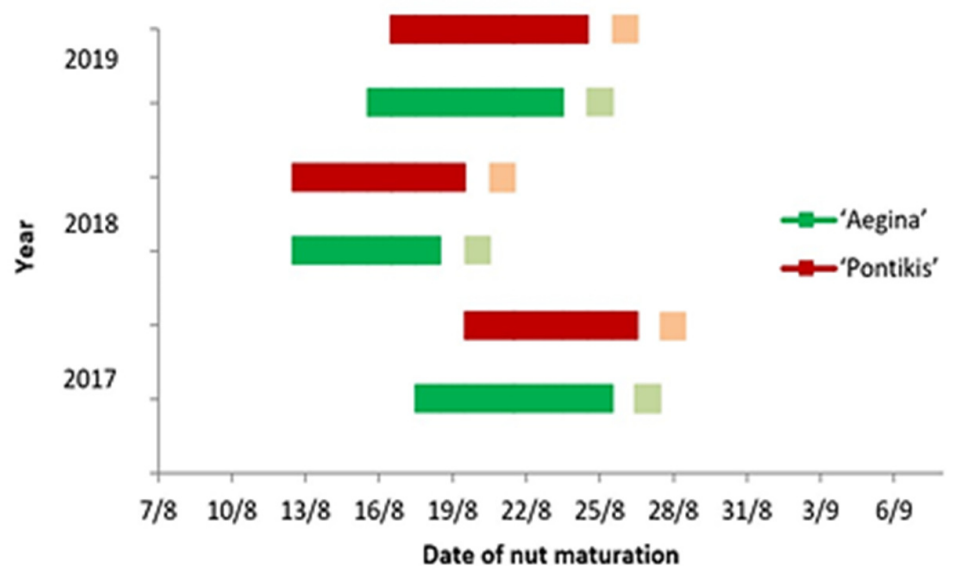

Figure 5. Fruit maturation period (dark colours) and harvest time (light colours) of 'Aegina' and 'Pontikis' cultivar

Production of trees of 'Aegina' cultivar started at 6th to 7 th year from grafting, while full production observed in the $13^{\text {th }}$ year, whereas 'Pontikis' cultivar production started after 6 or 7 years from grafting, with full production observed at 14th year. Similar, Vargas et al. (1995) reported that among female cultivars studied 'Aegina' has a short juvenile period (score 4; 1 long to 5 short). 'Aegina's' mean tree yield for the years of full production ("on" year) reached $18.0 \pm 1.0 \mathrm{~kg}$ of dry nuts and 'Pontikis' $17.4 \pm 1.1 \mathrm{~kg}$ of dry nuts. Tree yield is an important and useful parameter that must be considering, when choosing a cultivar. Abidi (2016) reported that in Tunisia with Mediterranean climate, 'Mateur' cultivar was the most productive one with $4.1 \mathrm{~kg} / \mathrm{tree}$, the least productive was 'Elguetar' with an average of $1.4 \mathrm{~kg} /$ tree, while 'Kerman' and 'Ohadi' produced 2.1 $\mathrm{kg} /$ tree, under standard conditions of irrigation, fertilization, pruning, pollination and pest and disease control, yields lower enough from ours. In our study, the two Greek pistachio cultivars evaluated could be considered as high productive that could offer a sufficient profit to pistachio stakeholders. Considering the plantation distances $(7 \times 7 \mathrm{~m})$, approximately 200 trees per ha are planted. Mean productivity of 'Aegina' cultivar could be calculated at $3600 \mathrm{~kg} \mathrm{ha}^{-1}$ and that of 'Pontikis' cultivar at $3480 \mathrm{~kg} \mathrm{ha}^{-1}$. The estimated yields of the two cultivars are comparative to those reported by Kallsen et al. (2009), who reported mean yields of $3402 \mathrm{~kg} \mathrm{ha}^{-1}$ for the 'Kerman' cultivar, $4313 \mathrm{~kg} \mathrm{ha}^{-1}$ and $3244 \mathrm{~kg} \mathrm{ha}^{-1}$ for the two University of California-bred cultivars 'Golden Hills' and 'Lost Hills', respectively, as well as $2845 \mathrm{~kg} \mathrm{ha}^{-1}$ and $2423 \mathrm{~kg} \mathrm{ha}^{-1}$ for the Iranian 'Kalehghouchi' and 'Aria' cultivars, respectively, all cultivated in northwestern Kern County.

The trees of 'Aegina' cultivar from the collection presented intermediate vigor with spreading growth habit and compound leaves with 3 to 5 leaflets, whereas the trees of 'Pontikis' cultivar presented high vigor with semi-erect growth habit and compound leaves with 3 to 5 leaflets (Table 1). These differences on tree vigor and growth habit indicate diversity between the two cultivars, although their same area of origin. However, Vargas et al. (1995) reported that 'Aegina' cultivar in the collection of Mas Bové (Tarragona) showed low vigor, whereas in the first evaluation of Rouskas (2002) of young trees of the same collection, 'Aegina' cultivar showed 
intermediate vigour with spreading growth habit and 'Pontikis' cultivar high vigor with semi-erect growth habit.

Table 1. Most highly discriminative descriptors of 'Aegina' and 'Pontikis' pistachio cultivars (mean 20172019)

\begin{tabular}{|c|c|c|}
\hline Most highly discriminative descriptors ${ }^{1}$ & 'Aegina' & 'Pontikis' \\
\hline Tree vigour & Intermediate $(5)^{2}$ & $\operatorname{High}(7)$ \\
\hline Growth habit & Spreading (3) & semi-erect (2) \\
\hline Number of leaflets & 3 to 5 & 3 to 5 \\
\hline Nut shape & Narrowly cordate (4) & Ovoid $(2 ; 1.5<1 / \mathrm{w}<1.8)$ \\
\hline Shell apex & Symmetrically pointed (3) & Symmetrically pointed (3) \\
\hline Depression of shell near pedicel scar & Absent $(0)$ & Slight $(1)$ \\
\hline Pedicel scar shape & Elliptic (3) & Elliptic (3) \\
\hline Pedicel scar elevation & Protruding (2) & Protruding (2) \\
\hline Suture elevation & Low $(3)$ & Low $(3)$ \\
\hline Split nuts (\%) & $78.5 \pm 6.5$ & $84.1 \pm 6.2$ \\
\hline Position of suture opening & Mainly ventral side (4) & Mainly ventral side (4) \\
\hline Suture opening & $\begin{array}{l}\text { Mostly moderate to narrow } \\
\text { (5 to } 3)\end{array}$ & Mostly moderate to wide ( 5 to 7 ) \\
\hline Narrow suture opening (\%) & 33.0 & 15.3 \\
\hline Moderate suture opening (\%) & 45.8 & 54.1 \\
\hline Wide suture opening (\%) & 21.2 & 30.6 \\
\hline 100-Nut weight $(\mathrm{g})$ & 101.0 & 114.4 \\
\hline Number of nuts in $100 \mathrm{~g}$ & 99.0 & 87.4 \\
\hline 100-Kernel weight $(\mathrm{g})$ & 52.3 & 65.1 \\
\hline Kernel colour & Yellowish green (2) & Green (3) \\
\hline Testa colour & Reddish (2) & Reddish (2) \\
\hline
\end{tabular}

${ }^{1}$ According to IPGR (1997) descriptors for pistachio

${ }^{2} \mathrm{Numbers}$ in parentheses refer to the respective description according to IPGR (1997)

\section{Fruit characteristics}

According to IPGRI (1997), in-shell nuts of 'Aegina' cultivar had a narrowly cordate shape with a symmetrically pointed shell apex and absent depression of shell near pedicel scar. The shape of pedicel scar was evaluated as elliptic and its elevation as protruding (Figure 6a). The split nut was found $78.5 \pm 6.5 \%$. Regarding the suture opening of split nuts, it was revealed that most of the nuts (45.8\%) presented moderate suture opening, $33.0 \%$ of the nuts narrow and $21.2 \%$ of the nuts wide suture opening. Position of suture opening was noticed mainly in the ventral side. The weight of 100 nuts was found $101.0 \mathrm{~g}$ and that of the 100 kernels 52.3 $\mathrm{g}$, whereas in $100 \mathrm{~g}$ of weight a mean of 99.0 nuts were measured. Colour of kernel was evaluated as yellowish green and kernels' testa as reddish (Table 1; Figure 6a). Fruit measurements taken from 2017 to 2019 revealed a mean nut width of $11.1 \pm 0.6 \mathrm{~mm}$, nut thickness $11.2 \pm 0.7 \mathrm{~mm}$, nut length $20.8 \pm 0.9 \mathrm{~mm}$, nut size index $14.4 \pm 0.5 \mathrm{~mm}$, nut shape index $0.78 \pm 0.02$, nut weight $1.01 \pm 0.11 \mathrm{~g}$, kernel weight $0.52 \pm 0.07 \mathrm{~g}$ and kernel efficiency $51.7 \pm 2.5 \%$ (Table 2). 

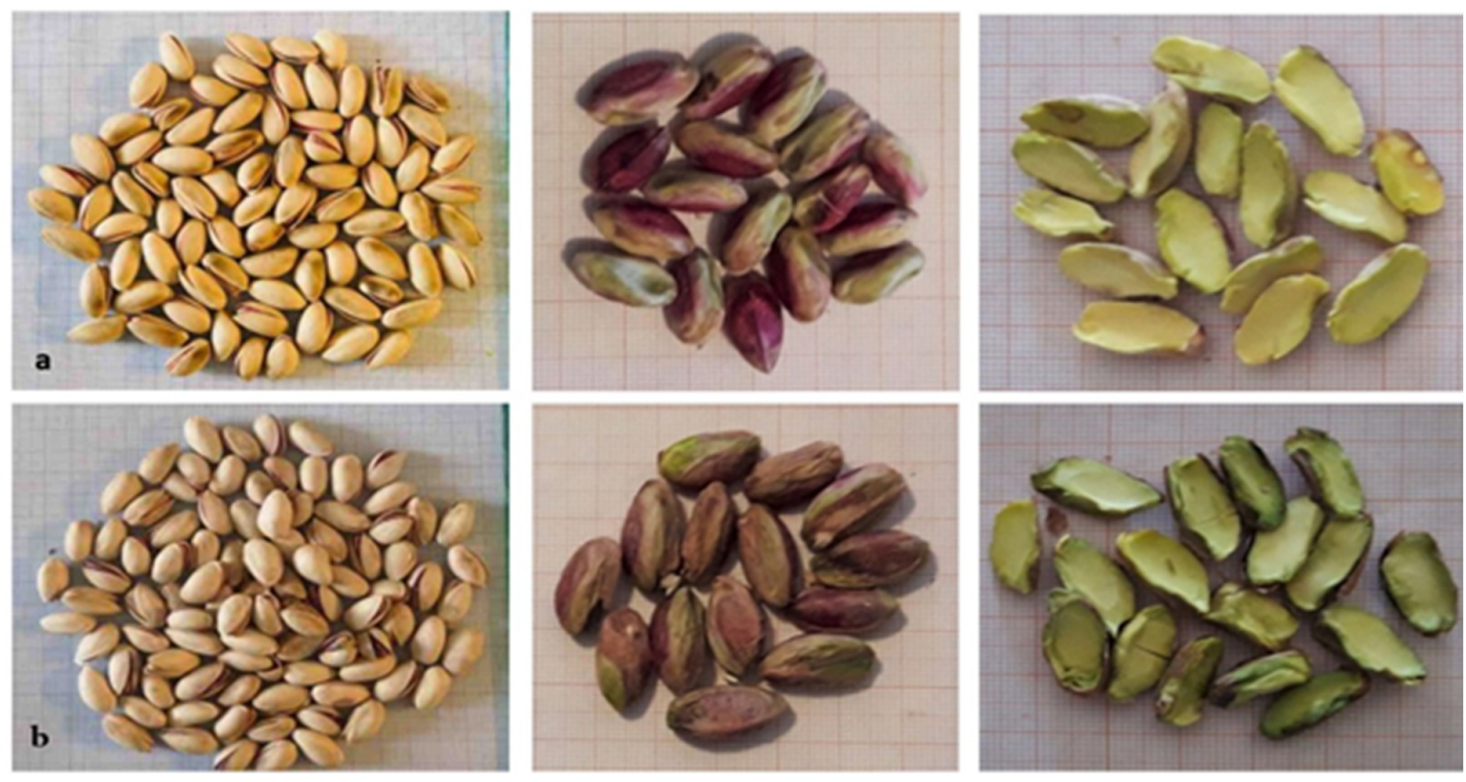

Figures 6. Nuts and kernels of 'Aegina' (a) and 'Pontikis' (b) pistachio cultivar (Manthos I., personal file)

Table 2. Pistachio nut characteristics of 'Aegina' and 'Pontikis' cultivars (mean 2017-2019)

\begin{tabular}{|c|c|c|c|c|c|c|c|c|}
\hline Parameter & $\begin{array}{c}\text { Nut } \\
\text { width } \\
(\mathrm{W}) \\
(\mathrm{mm})\end{array}$ & $\begin{array}{c}\text { Nut } \\
\text { thickness } \\
(\mathrm{T}) \\
(\mathrm{mm})\end{array}$ & $\begin{array}{c}\text { Nut } \\
\text { length } \\
(\mathrm{L}) \\
(\mathrm{mm})\end{array}$ & $\begin{array}{c}\text { Nut } \\
\text { size } \\
\text { index }\end{array}$ & $\begin{array}{c}\text { Nut } \\
\text { shape } \\
\text { index }\end{array}$ & $\begin{array}{c}\text { Nut } \\
\text { weight } \\
(\mathrm{g})\end{array}$ & $\begin{array}{c}\text { Kernel } \\
\text { weight } \\
(\mathrm{g})\end{array}$ & $\begin{array}{c}\text { Kernel } \\
\text { efficiency } \\
(\%)\end{array}$ \\
\hline Mean & 11.1 & 11.2 & 20.8 & 14.4 & 0.5 & 1.0 & 0.5 & 51.7 \\
\hline Min & 9.8 & 9.4 & 18.6 & 12.6 & 0.5 & 0.7 & 0.3 & 40.5 \\
\hline Max & 12.9 & 12.4 & 22.2 & 15.8 & 0.6 & 1.2 & 0.7 & 57.1 \\
\hline Variance & 0.3 & 0.5 & 0.7 & 0.2 & 0.001 & 0.01 & 0.004 & 6.1 \\
\hline Standard deviation & 0.6 & 0.7 & 0.9 & 0.6 & 0.02 & 0.1 & 0.1 & 2.5 \\
\hline \multicolumn{7}{|c|}{ 'Pontikis' cultivar } \\
\hline Mean & 11.9 & 11.2 & 20.3 & 14.5 & 0.6 & 1.1 & 0.7 & 56.8 \\
\hline Min & 10.9 & 10.1 & 18.4 & 13.6 & 0.6 & 0.8 & 0.5 & 50.0 \\
\hline Max & 13.0 & 12.4 & 21.4 & 15.5 & 0.6 & 1.4 & 0.8 & 62.9 \\
\hline Variance & 0.4 & 0.5 & 0.8 & 0.2 & 0.001 & 0.01 & 0.01 & 5.6 \\
\hline Standard deviation & 0.6 & 0.7 & 0.9 & 0.5 & 0.1 & 0.1 & 0.1 & 2.4 \\
\hline
\end{tabular}

'Pontikis' in-shell pistachio nuts had ovoid shape with a symmetrically pointed shell apex and slight depression of shell near pedicel scar. The shape of pedicel scar was evaluated as elliptic and its elevation as protruding (Figure $6 \mathrm{~b}$ ). The spilt nuts were found $84.1 \pm 6.2 \%$. Regarding the suture opening of split nuts, it was revealed that most of the nuts $(54.1 \%)$ presented moderate suture opening, $30.6 \%$ of the nuts wide and only $15.3 \%$ of the nuts presented narrow suture opening. Position of suture opening was noticed mainly in the ventral side. The weight of 100 nuts was found $114.4 \mathrm{~g}$ and that of the 100 kernels $65.1 \mathrm{~g}$, whereas in $100 \mathrm{~g}$ of weight a mean of 87.4 nuts were measured. Colour of kernel was evaluated as green, greener than 'Aegina' variety and kernels' testa as reddish (Table 1; Figure 6b). Fruit measurements taken from 2017 to 2019 revealed a mean nut width of $11.9 \pm 0.6 \mathrm{~mm}$, nut thickness $11.2 \pm 0.7 \mathrm{~mm}$, nut length $20.3 \pm 0.9 \mathrm{~mm}$, nut size index $14.59 \pm 0.5 \mathrm{~mm}$, nut shape index $0.80 \pm 0.02$, nut weight $1.14 \pm 0.12 \mathrm{~g}$, kernel weight $0.65 \pm 0.08 \mathrm{~g}$ and kernel efficiency $56.8 \pm 2.4 \%$ (Table 2 ). 
According to these data, it is revealed that there are differences on fruit characteristics between the two cultivars. Most important is nut splitting, an important trait affecting the commercialization of the nuts, as split nuts are preferred by consumers. Moreover, this characteristic is considered to related by physiological ripening and growing conditions factors, but it has also important genetic status (Padulosi and Hadj-Hassan, 2001). Percentage of split nut was found higher in 'Pontikis' cultivar relative to 'Aegina' ( $84.1 \pm 6.2 \%$.vs $78.5 \pm 6.5 \%$, respectively). Concerning suture opening of split nuts, the percentage of nuts with wide suture opening was higher in 'Pontikis' cultivar relative to 'Aegina' (30.6\% vs $21.3 \%$ respectively). Moreover, other fruit parameters such as nut weight, kernel weight, kernel efficiency, the weight of 100 nuts and that of the 100 kernels were all found higher in 'Pontikis' pistachio relative to 'Aegina'.

According to Rouskas (2002), the percentage of split nut was 54\% for 'Aegina' cultivar and $85 \%$ for 'Pontikis' cultivar. The lower percentage found in 'Aegina' cultivar relative to our data might be due to ripening and growing conditions, but also due to climatic conditions and the younger age of the trees. High percentage of split nuts (90-98\%) and wide suture opening (3/4) of 'Pontikis' cultivar was found by Pontikis (1986). In both studies of Vargas et al. (1995) and Padulosi and Hadj-Hassan (2001) nut splitting of 'Aegina' cultivar was rather lower (39\% and $35.41 \%$, respectively) relative to our observation. These observations might be also due to ripening, growing and climatic conditions and tree age. Moreover, in the study of Tsantili et al. (2010) on the same collection with the present study, but in younger trees, it was found that spilt percentage of 'Aegina' nuts was $80.2 \%$, whereas that of 'Pontikis' $91.2 \%$.

Regarding nut characteristics, concerning nut weight, kernel weight and kernel efficiency, Rouskas (2002) found higher kernel efficiency in 'Aegina' cultivar (56\%) due to higher kernel weight $(0.59 \mathrm{~g})$, but similar kernel efficiency in 'Pontikis' cultivar (56\%), although lower nut and kernel weight ( $1.02 \mathrm{~g}$ and $0.58 \mathrm{~g}$, respectively), in relation to our findings for this cultivar. Kernel efficiency in the study of Tsantili et al. (2010) was found at $54.81 \%$ and $57.24 \%$ for 'Aegina' and 'Pontikis' cultivar, respectively. Moreover, approximately similar results with us were obtained from the same authors regarding nut length and width of both cultivars. Pontikis (1986) found that kernel efficiency of nuts of 'Pontikis' cultivar was 54.6\% (kernel weight $0.62 \mathrm{~g}$ and shell weight $0.51 \mathrm{~g}$ ). Small differences (lower values) on nut length, width, thickness, nut weight, nut kernel and kernel efficiency were obtained by Padulosi and Hadj-Hassan (2001) for 'Aegina' cultivar in different area and conditions of cultivation (collection of Mas Bové (Tarragona)). However, almost similar values for the same traits were obtained from the study of Vargas et al. (1995) for 'Aegina' cultivar in the collection of Mas Bové (Tarragona). According to authors, considering all the results obtained from the 29 females' pistachio cultivars of their collection, 'Aegina' cultivar is one of the most promising female cultivar in the specific area of cultivation (Mediterranean area).

\section{Fruit antioxidant potential}

The antioxidant potential of pistachio kernel samples of the two cultivars examined, was measured by the following different assays, total antioxidant activity using FRAP assay and total polyphenolic substances, flavonoids, hydroxycinnamic acids and flavanols content. FRAP value in kernels of 'Aegina' cultivar was found at $759.9 \pm 6.3 \mathrm{mg}$ Trolox / 100g fw, whereas that of 'Pontikis' cultivar at $760.0 \pm 7.0 \mathrm{mg}$ Trolox / $100 \mathrm{~g} \mathrm{fw}$ (Figure 7). No statistical difference $(P>0.05)$ was observed in FRAP values between the two cultivars. Total polyphenols content did not also differ between cultivars $(\mathrm{P}>0.05)$, being $458.2 \pm 106.7 \mathrm{mg}$ gallic acid / 100g fw and $476.1 \pm 17.3 \mathrm{mg}$ gallic acid / 100g fw, in 'Aegina' and 'Pontikis' cultivar, respectively (Figure 8). Flavonoids in 'Aegina' kernels were found at $2498.0 \pm 693.9 \mathrm{mg}$ routin / $100 \mathrm{~g}$ fw and $2586.2 \pm 221.2 \mathrm{mg}$ routin / $100 \mathrm{~g}$ fw in 'Pontikis' cultivar, with no statistical difference $(\mathrm{P}>0.05)$ between values (Figure 9). Hydroxycinnamic acids content was found at $1046.9 \pm 241.2 \mathrm{mg}$ caffeic acid / $100 \mathrm{~g} \mathrm{fw}$ in 'Aegina' cultivar and $982.5 \pm 111.8 \mathrm{mg}$ caffeic acid / $100 \mathrm{~g}$ fw in 'Pontikis' cultivar (Figure 10), whereas flavanols content was found at $170.0 \pm 20.2 \mathrm{mg}$ quercetin / $100 \mathrm{~g} \mathrm{fw}$ in 'Aegina' cultivar and $157.4 \pm 13.9 \mathrm{mg}$ quercetin / $100 \mathrm{~g} \mathrm{fw}$ in 'Pontikis' cultivar (Figure 11). No significant differences $(\mathrm{P}>0.05)$ were observed between cultivars, neither on hydroxycinnamic acids values nor on flavanols content. 


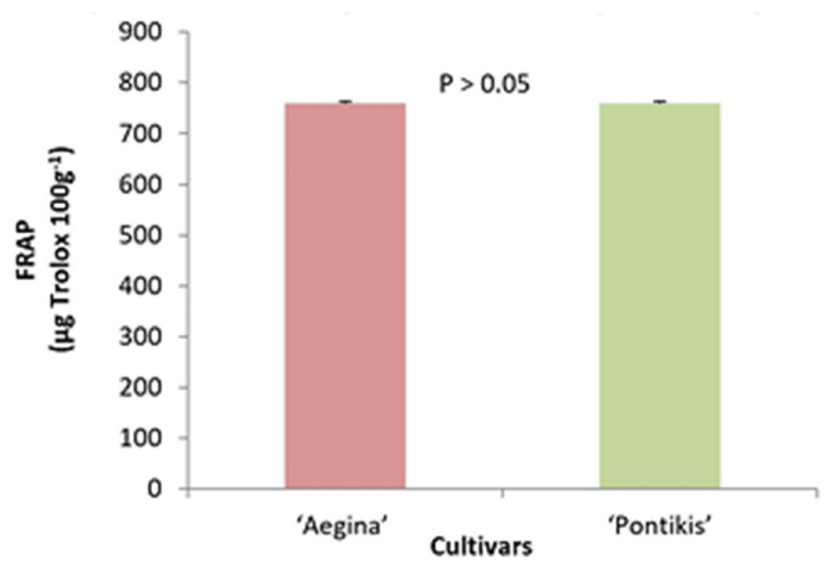

Figure 7. FRAP activity of 'Aegina' and 'Pontikis' cultivar nuts Data are presented as mean \pm SE

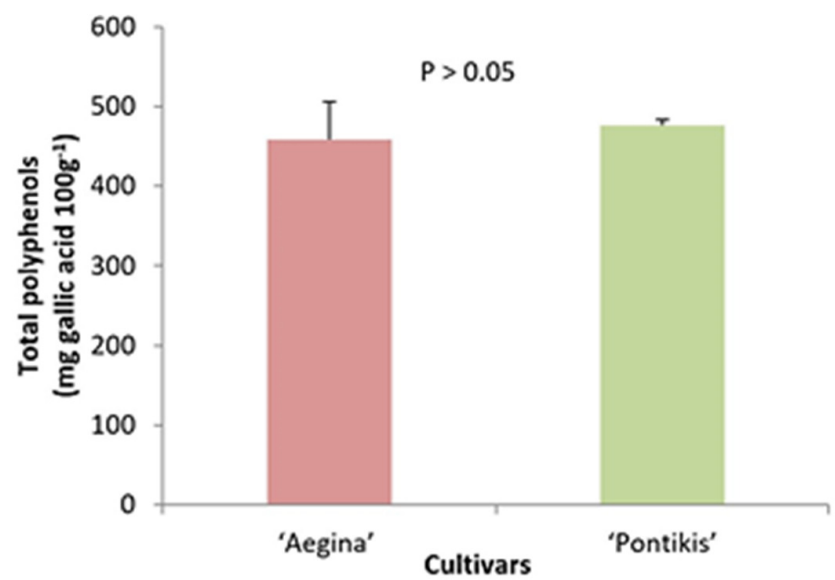

Figure 8. Total polyphenols content (mean \pm SE) of 'Aegina' and 'Pontikis' cultivar nuts Data are presented as mean $\pm \mathrm{SE}$

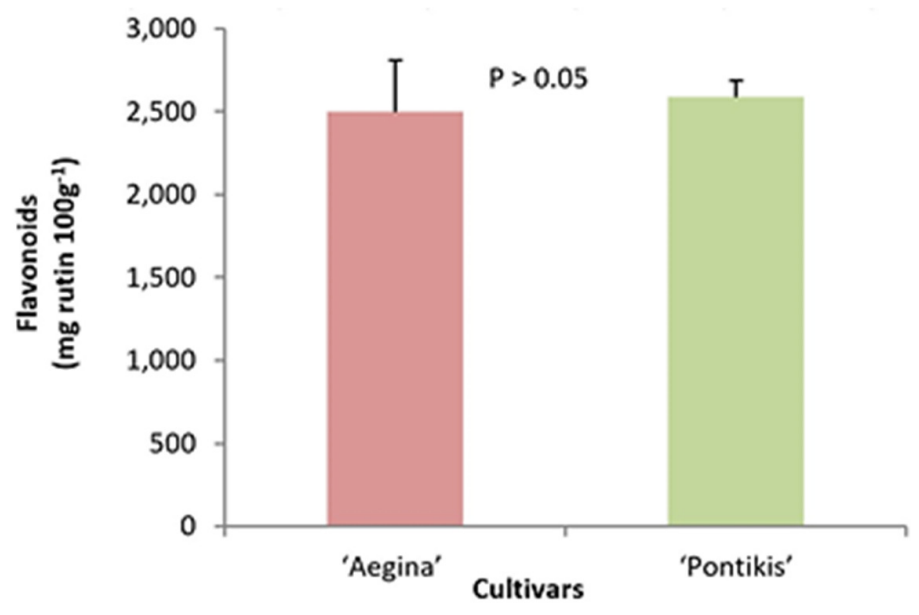

Figure 9. Flavonoids content of 'Aegina' and 'Pontikis' cultivar nuts Data are presented as mean \pm SE 


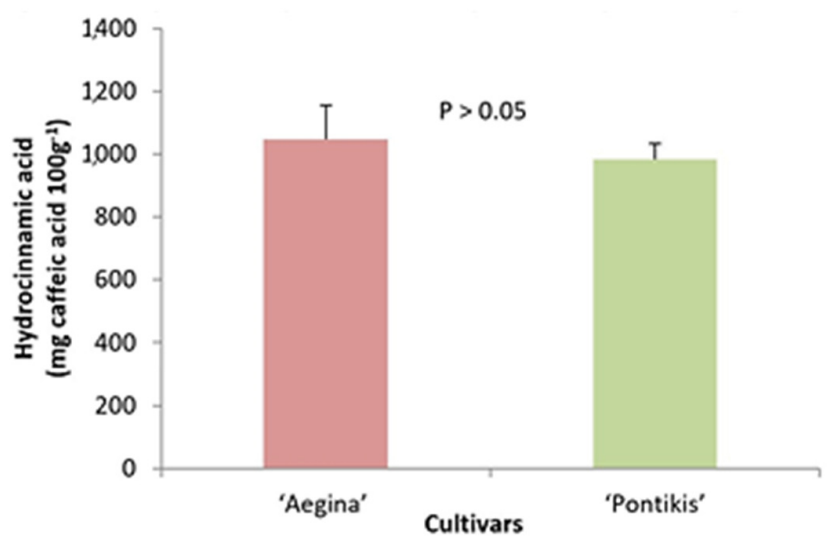

Figure 10. Hydrocinnanic acid content of 'Aegina' and 'Pontikis' cultivar nuts Data are presented as mean $\pm \mathrm{SE}$

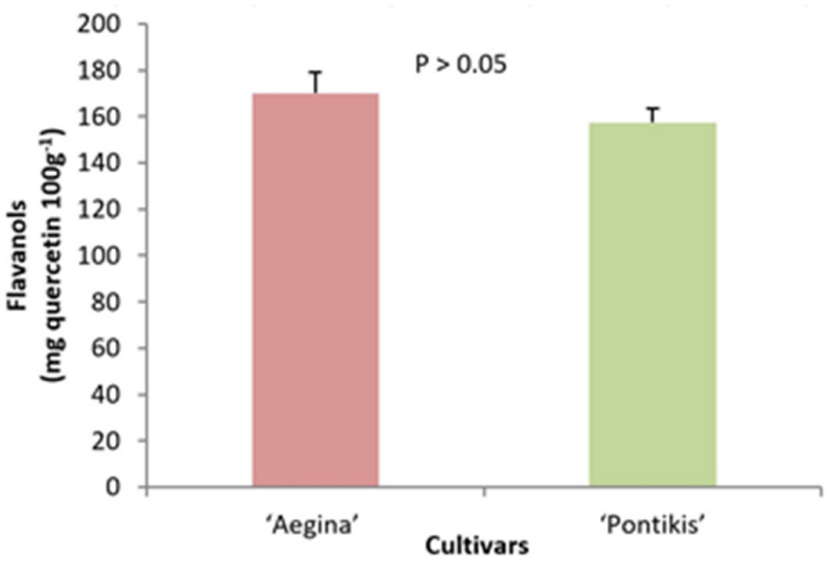

Figure 11. Flavanols content of 'Aegina' and 'Pontikis' cultivar nuts

Data are presented as mean \pm SE

All the above data revealed that the antioxidant potential of the edible part of dried nuts is similar among the two cultivars, under the same cultivation practices and climate conditions, in the same cultivation area. In another study of Tsantili et al. (2011), on different pistachio cultivars kept in the same collection of ours, they evaluated the effects of cultivar, drying and storage conditions on total phenolics (TP), total flavonoids (TF) and total antioxidant capacity (TAC), measured with ferric reducing antioxidant power (FRAP) and radical scavenging capacity (2,2-diphenyl-1-picrylhydrazyl or DPPH) assays, of in-shell and unpeeled kernels of ripe. Authors found that among the studied cultivars, 'Pontikis', 'Aegina', 'Bronte' and 'Cerasola' showed higher TP, TF and TAC than 'Sirora', 'Kerman', 'Joley' and 'Mumtaz' cultivars, in all cases, while 'Pontikis' had the highest values in most cases. It is known that pistachio nuts are a rich source of natural antioxidants, sterols, vitamins, minerals, fatty acids and phenolic compounds and thus may be considered an "unique functional food", and have recently been ranked among the first 50 food products highest in antioxidant potential (Halvorsen et al., 2006). The phenolic compounds contained in pistachio nuts (anthocyanins, flavan-3-ols, proanthocyanidins, flavonols, isoflavons, flavanones, stilbenes, and phenolic acids) are known for their high antioxidant activity (Lau et al., 2006), as well as for their chemopreventive, cardioprotective and vasoprotective capacities (Agouni et al., 2009). The composition of pistachio kernel may vary depending on the cultivar, cultivation site, climate, and horticultural practice (Agar et al., 1995; Tajabadipour et al., 2006; Tavallali and Rahemi 2007; Tsantili et al., 2011; Nadernejad et al., 2012). 


\section{Phenotypic analysis}

In order to identify the most crucial variables, a principal component analysis (PCA) analysis was conducted for all the evaluated parameters in the examined accessions. A factor map was created, which illustrates the way by which these pistachio accessions are grouped based on their origins (Figure 12). To exploit the similarities, as well as the differences of each variable between the accessions, we performed a clustered heatmap analysis (Figure 13). The PCA model explained a variation of $83.4 \%$ and $15.2 \%$ by first and second components. Cluster displaying the relationships among the sixteen pistachio accessions tested separates them into two main groups.

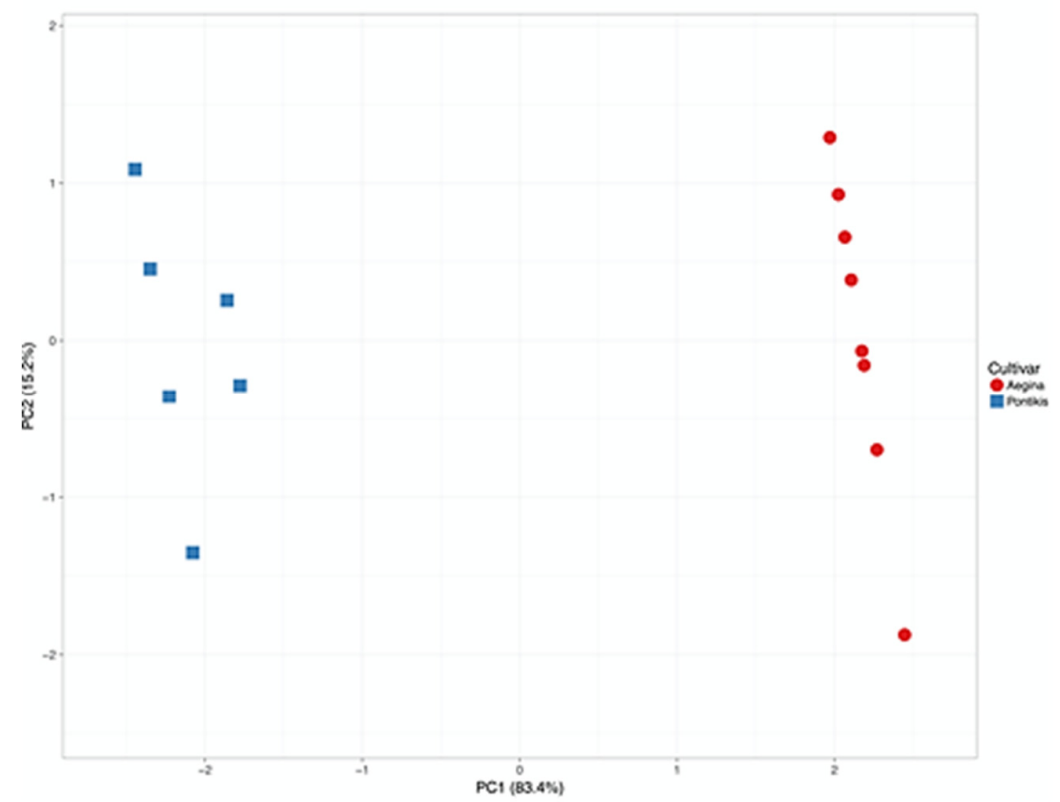

Figure 12. Principal component analysis (PCA) score plot of all evaluated variables for all tested pistachio accessions

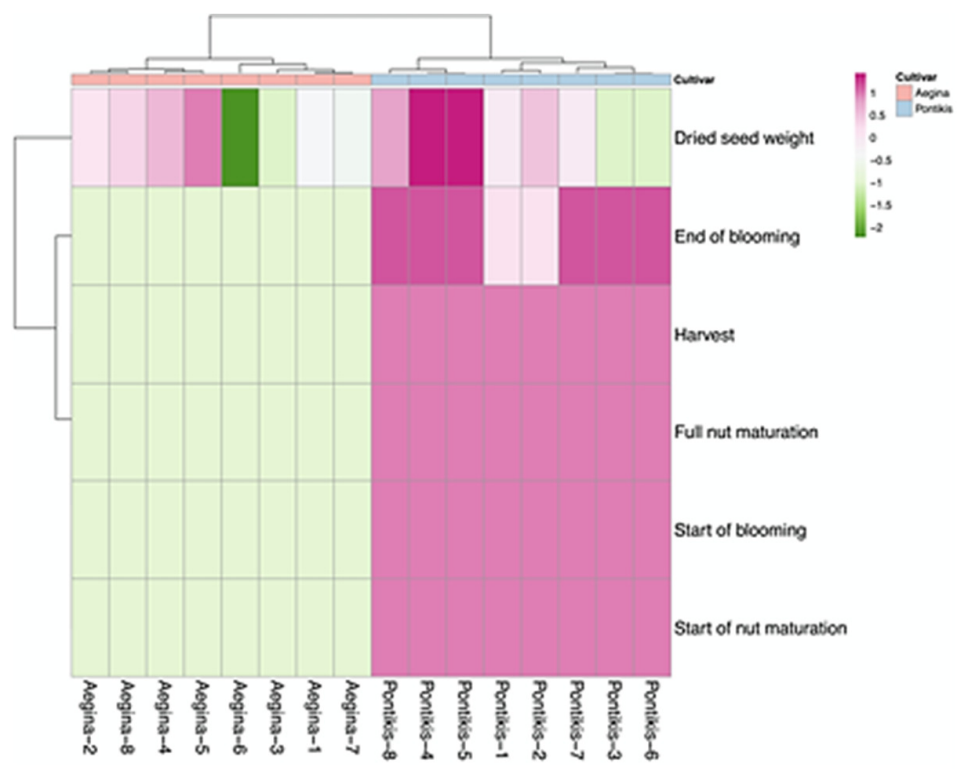

Figure 13. Cluster heatmap profiling of pistachio cultivars 


\section{Conclusions}

'Aegina' and 'Pontikis' are the dominant cultivated pistachio varieties in Greece, that are well adapted to Mediterranean climate conditions. Both are high yielding cultivars, competitive to foreign ones, with large nut sizes of acceptable appearance and high quality. Their response in the conditions of culture in Central Greece strengths their value and sustain their use into private farms and in fact with an income significantly higher than the income of other types of crops (i.e. cotton, cereals, etc).

\section{Authors' Contributions}

Conceptualization: IM. Work on the field: IM and DR. Methodology: IM, DR and MB. Software: IM, TS. Calculations: IM and AM. Formal analysis: IM, EK, AM and MB. Literature: IM and TS. Data curation: IM, EK, AM and MB. Writing - original draft preparation, IM. Writing - review and editing: IM and MB. Visualization: IM. Supervision, IM. Project administration: IM.

All authors read and approved the final text of the manuscript.

\section{Acknowledgements}

This research received no specific grant from any funding agency in the public, commercial, or not-forprofit sectors.

\section{Conflict of Interests}

The authors declare that there are no conflicts of interest related to this article.

\section{References}

Abidi W (2016). Pomological and physical attributes of pistachio (Pistacia vera L.) varieties grown in west-central Tunisia. Journal of New Sciences, Agriculture and Biotechnology 28(4):1582-1588.

Agar I, Kaska N, Kafkas S (1995). Characterization of lipids in Pistacia species grown in Turkey. Acta Horticulturae 419:417-422. https://doi.org/10.17660/ActaHortic.1995.419.69

Agouni A, Lagrue-Lak-Hal AH, Mostefai HA, Tesse A, Mulder P, Rouet P, ... Andriantsitohain R (2009). Red wine polyphenols prevent metabolic and cardiovascular alterations associated with obesity in Zucker fatty rats (Fa/Fa). PLoS One 4:1e8. https://doi.org/10.1371/journal.pone.0005557

Asami DK, Hong YJ, Barrett DM, Mitchell AE (2003). Processing-induced changes in total phenolics and procyanidins in clingstone peaches. Journal of the Science of Food and Agriculture 83:56-63. https://doi.org/10.1002/jsfa.1275

Benzie IFF, Strain JJ (1996). The ferric reducing ability of plasma (FRAP) as a measure of "antioxidant power": The FRAP assay. Analytical Biochemistry 239(1):70-76. https://doi:10.1006/abio.1996.0292

Bouyoukos GJ (1951). A recalibration of the hydrometer method for making mechanical analysis of soils. Agronomy Journal 43:434-438. https://doi.org/10.2134/agronj1951.00021962004300090005x

Chandler WH, Kimball MH, Phillips GL, Tufts WP, Weldon GP (1937). Chilling requirements for opening buds on deciduous orchard trees and some other plants in California. University of California Agricultural Experiment Station, Bulletin, pp 611.

FAO (2019). Stat Database Web Page. www.fao.org

Georgiadou M (2009) Study of aflatoxine incidence in pistachio nut. MSc Dissertation, Agricultural University of Athens. 
Halvorsen BL, Carlsen MH, Phillips KM, Bøhn SK, Holte K, Jacobs Jr DR, Blomhoff R (2006). Content of redox-active compounds (i.e., antioxidants) in food consumed in the United States. The American Journal of Clinical Nutrition 84:95-135. https://doi.org/10.1093/ajcn/84.1.95

IPGRI (1997). Descriptors for pistachio (Pistacia vera L.). International Plant Genetic Resources Institute, Rome, Italy. Jackson ML (1958). Soil chemical analysis. Prentice-Hall, Inc., Englewood Cliffs, New Jersey pp 111-133.

Kallsen C, Parfitt D, Maranto J, Holtz B (2009). New pistachio varieties show promise for California cultivation. California Agriculture 63(1):18-23. https://doi.org/10.3733/ca.v063n01p18

Karagiannis E, Tanou G, Samiotaki M, Michailidis M, Diamantidis G, Minas IS, ... Molassiotis A (2016). Comparative physiological and proteomic analysis reveal distinct regulation of peach skin quality traits by altitude. Frontiers in Plant Science 7:1-14. https://doi:10.3389/fpls.2016.01689

Katsiotis A, Hagidimitriou M, Drossou A, Pontikis C, Loukas (2003). Genetic relationships among species and cultivars of Pistacia using RAPDs and AFLPs. Euphytica 132:279-286. https://doi.org/10.1023/A:1025027323184

Kocyigit A, Koylu AA, Keles H (2006). Effects of pistachio nuts consumption on plasma lipid profile and oxidative status in healthy volunteers. Nutrition, Metabolism and Cardiovascular Diseases 16(3):202-209. https://doi.org/10.1016/j.numecd.2005.08.004

Lau FC, Shukitt-Hale B, Joseph JA (2006) The beneficial effects of fruit polyphenols on juice on cognitive and motor deficits in aging. Nutrition 22:295-302.

Manthos I, Rouskas D, Sotiropoulos T, Michailides TJ, Bizera M, Botu M (2019). Evaluation of two main Greek pistachio varieties. Analele Universității din Craiova, Seria Horticultura, Biologie, Ingineria Mediului XXIV(LX):117121.

Metheney PD, Reyes HC, Ferguson L (1998). Blended drainage water irrigation of pistachios, cv. 'Kerman', on four rootstocks in the southern San Joaquin Valley of California. Acta Horticulture 470:493-501. https://doi.org/10.17660/ActaHortic.1998.470.69

Metsalu T, Vilo J (2015). ClustVis: a web tool for visualizing clustering of multivariate data using Principal Component Analysis and heatmap. Nucleic Acids Research 43:W566-W570. https://doi.org/10.1093/nar/gkv468

Michailidis M, Karagiannis E, Tanou G, Karamanoli K, Lazaridou A, Matsi T, Molassiotis A (2017). Metabolomic and physico-chemical approach unravel dynamic regulation of calcium in sweet cherry fruit physiology. Plant Physiology and Biochemistry 116:68-79. https://doi.org/10.1016/j.plaphy.2017.05.005

Mohsenin NN (1980) Physical properties of plant and animal materials. Gordon and Breach Science Publishers, New York.

Nadernejad N, Ahmadimoghadam A, Hossyinifard J, Poorseyedi S (2012). Phenylalanin ammonia-Lyase activity, total phenolic and flavonoid contents in flowers, leaves, hulls and kernels of three pistachio (Pistacia vera L.) cultivars. American-Eurasian Journal of Agricultural and Environmental Science 12(6):807-814. https://doi:10.5829/idosiaejaes.2012.12.06.1746

Obied HK, Allen MS, Bedgood DR, Prenzler PD, Robards K (2005). Investigation of Australian olive mill waste for recovery of biophenols. Journal of Agricultural and Food Chemistry 53:9911-9920. https://doi.org/10.1021/jf0518352

Padulosi S, Hadj-Hassan A (2001). Towards a comprehensive documentation of distribution and use of Pistacia genetic diversity in Central and West Asia, North Africa, and Mediterranean Europe. Report of International Plant Genetic Resources Institute Workshop; 14-17 December 1998, Irdib Jordan. ISBN: 92-9043-512-7. Pistachia conservation, characterization and use at IRTA: current situation and prospects in Spain pp 77-87.

Pontikis CA (1986). 'Pontikis' pistachio. HortScience 21:1074.

Rouskas D, Zakinthinos G (1994). FAO-Nucis-Newletter, Number 2, April, 1994 pp 6-7. http://networks.iamz.ciheam.org/nuts/pdfs/NUCIS\%202_1994.pdf

Rouskas D (2002). First evaluation of twelve pistachio (P. vera L.) female cultivars. Acta Horticulture 591:519-523. https://doi.org/10.17660/ActaHortic.2002.591.79

Rouskas D (2005). Evaluation of Pistachia (Pistachia vera L.) cultivation perspectives in Fthiotida. Published in Lamic Press, sheet no. 18483, pp 9-10.

Rouskas, D., Akrivos I, Tsantili E, Takidelli X (2006). Pistachio varieties monographs (description). NAGREF Journal 27:7-14.

SPSS Inc. Released (2008). SPSS Statistics for Windows, Version 17.0. Chicago: SPSS Inc.

Tajabadipour A, Panahi B, Zadehparizi R (2006). The effects of rootstock and scion on early splitting and cracked hull of pistachio. Acta Horticulture 726:193-198. https://doi.org/10.17660/ActaHortic.2006.726.29 
Tavallali V, Rahemi M (2007). Effect of rootstock on nutrient acquisition by leaf, kernel and quality of pistachio (Pistacia vera L.). American-Eurasian Journal of Agricultural \& Environmental Science 2:240-246.

Tsantili E, Takidelli C, Christopoulos M, Lambrinea E, Rouskas D, Roussos P (2010). Physical, compositional, and sensory differences in nuts among pistachio (Pistachia vera L.) varieties. Scientia Horticulturae 125(4):562-568. https://doi.org/10.1016/j.scienta.2010.04.039

Tsantili E, Konstantinidis K, Christopoulos M, Roussos P (2011). Total phenolics and flavonoids and total antioxidant capacity in pistachio (Pistachia vera L.) nuts in relation to cultivars and storage conditions. Scientia Horticulturae 129(4):694-701. https://doi.org/10.1016/j.scienta.2011.05.020

Vargas FJ, Romero M, Plana J, Rovira M, Batlle I (1995). Characterization and behaviour of pistachio cultivars in Catalonia (Spain). Acta Horticulturae 419:181-188. https://doi.org/10.17660/ActaHortic.1995.419.29

Zohary M (1952). A monographic study of the genus Pistachia. Palestine Journal of Botany (Jerusalem Series) 5(4):187228.
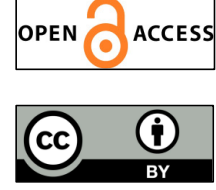

The journal offers free, immediate, and unrestricted access to peer-reviewed research and scholarly work. Users are allowed to read, download, copy, distribute, print, search, or link to the full texts of the articles, or use them for any other lawful purpose, without asking prior permission from the publisher or the author.

License - Articles published in Notulae Botanicae Horti Agrobotanici Cluj-Napoca are Open-Access, distributed under the terms and conditions of the Creative Commons Attribution (CC BY 4.0) License.

(c) Articles by the authors; UASVM, Cluj-Napoca, Romania. The journal allows the author(s) to hold the copyright/to retain publishing rights without restriction. 